\title{
PENGARUH ASIMETRI KONFLIK TUGAS TERHADAP KINERJA DAN PERAN MANAJEMEN KONFLIK KOLABORASI (Kasus pada Organisasi Non Profit) \\ Dwita Darmawati ${ }^{*}$, Tohir $^{2}$ dan Anisa Sri Restanti ${ }^{3}$ \\ Fakultas Ekonomi dan Bisnis, Universitas Jenderal Soedirman \\ *Email corresponding author: dwitadarma75@gmail.com
}

\begin{abstract}
ABSTRAK
Penelitian ini bertujuan untuk menggali pengaruh komposisi konflik tugas perseptual terhadap kinerja kelompok pada organisasi non profit. Selain itu penelitian ini juga menggali peran pemoderasina manajemen konflik kolaborasi pada pengaruh komposisi konflik tugas perseptual terhadap kinerja kelompok. Pengumpulan data dilakukan dengan kusioner. Data dianalisis dengan menggunakan analisis regresi hirarkis. Penelitian ini melibatkan 232 responden berasal $58 \mathrm{tim} / \mathrm{kelompok}$ kerja dari organisasi non profit yaitu pramuka perguruan tinggi, perpustakaan, lembaga pemerintahan tingkat desa, pendidikan anak usia dini, organisasi PKK dan dasa wisma. Hasil analisis regresi hirarkis menunjukkan bahwa komposisi konflik tugas perseptual berpengaruh negatif terhadap kinerja kelompok. Namun demikian, tidak ditemukan cukup bukti peran dari manajemen konflik kolaaborasi pada pengaruh komposisi konflik tugas perseptua terhadap kinerja kelompok. Beberapa implikasi diberikan berdasar hasil penelitian ini.
\end{abstract}

Kata kunci : asimetri konflik tugas, manajemen konflik kolaborasi, kinerja kelompok.

\begin{abstract}
This study aims to explore the influence of the composition of perceptual task conflicts on group performance in non-profit organizations. In addition, this study also explores the role of moderators of collaborative conflict management on the influence of the composition of perceptual task conflicts on group performance. Data collection is done by questionnaire. Data were analyzed using hierarchical regression analysis.

This study involved 232 respondents from 58 teams / working groups from non-profit organizations namely college scouts, libraries, village level government institutions, early childhood education, PKK organizations and dasa wisma. The results of hierarchical regression analysis indicate that the composition of perceptual task conflicts negatively affects group performance. However, there is not enough evidence of the role of collaboration conflict management in with the influence of the composition of the conflict on the task of the group on group performance. Several implications are given based on the results of this study.
\end{abstract}

Keywords: task conflicts asymmetry, collaborative conflict management, group performance

\section{Pendahuluan}

Wall \& Callister (1995) mendefinisikan konflik sebagai sebuah proses yang mana satu pihak merasakan bahwa kepentingannya berseberangan atau terpengaruh secara negatif oleh pihak yang lain. Meskipun secara luas diasumsikan bahwa konflik itu merusak, tetapi ketika dikelola dengan tepat, maka konflik akan membuat efektif kerja tim (Tjosvold, 2008).

Penelitian ini menggali pengaruh konflik tugas dalam kelompok terhadap kinerja dengan mempertimbangkan perbedaan persepsi terkait intensitas konflik diantara anggota kelompok, sesuatu yang sering diabaikan oleh peneliti konflik sebelumnya (Jehn, 1995; Bradley, Postlethwaite, Klotz, Hamdani, \& Brown, 2012; DeChurch, Mesmer- 
Magnus, \& Doty, 2013; Chang, 2017). Perbedaan persepsi ini dinamakan asimetri konflik tugas (Jehn, Rupert dan Nauta, 2006). Menurut Rahim (2010), perbedaan persepsi ini berpotensi secara signifikan memengaruhi kinerja dan kepuasan anggota kelompok.

Konsep asimetri konflik merujuk pada perbedaan persepsi anggota kelompok terkait intensitas konflik tugas yang terjadi pada kelompok (Jehn et al., 2010). Asimetri konflik tugas merupakan variasi atau dispersi dalam persepsi anggota tentang intensitas konflik tugas dalam kelompoknya. Kelompok dengan variansi tinggi menunjukkan keragaman persepsi di antara anggota kelompok terkait dengan konflik tugas.

Dengan menggunakan teori shared mental model (Mathieu, Heffner, Goodwin, Salas, \& Cannon-Bowers, 2000), penelitian ini akan menguji pengaruh asimetri konflik tugas terhadap kinerja kelompok khususnya pada organisasi non profit. Mathieu et al. (2000) mengemukakan bahwa shared Mental Model (SMM) mendasarkan pada ide bahwa kinerja tim akan membaik jika anggota mempunyai kesamaan pengetahuan dan informasi. Kesepakatan mengenai team mental model dan task mental model di antara anggotanya berpengaruh positif terhadap proses tim, dan selanjutnya berpengaruh positif juga pada kinerja tim.

Dipilihnya variabel kinerja karena pada umumnya variabel ini dianggap penting bagi keberhasilan dan kelangsungan hidup kelompok kerja (Balkundi \& Harrison, 2006; Hackman \& Wageman, 2005 dikutip dalam Jehn et al., 2010). Penelitian ini akan dilakukan pada organisasi non profit dengan pertimbangan bahwa organisasi ini mempunyai karakteristik yang khusus. Umumnya organisasi ini bergerak di bidang sosial atau organisasi pemerintah yang bertujuan untuk memberi pelayanan untuk masayarakat umum. Oleh karenanya, hasil penelitian ini diharapkan selain berkontribusi teoritis juga bermanfaat bagi praktisi untuk meningkatkan pelayanan pada masyarakat khususnya.

Hasil penelitian terdahulu yang memberikan hasil tidak konklusif. Konflik dalam kelompok memberikan dampak positif dan negatif bagi luarannya. Oleh karena itu, patut diduga adanya variabel moderator yang memengaruhi pengaruh konflik dalam kelompok terhadap luarannya tersebut. Wang \& Nasr (2010) menemukan bahwa gaya penanganan konflik yang menguntungkan dan paling disukai untuk menangani konflik tugas dengan kolega yang punya hubungan buruk adalah kolaborasi. Temuan De Dreu \& Vianen (2001) juga menunjukkan bahwa individu cenderung menggunakan manajemen konflik kolaborasi untuk penanganan konflik tugas, dan gaya manajemen konflik penghindaran untuk penanganan konflik hubungan.

Berdasarkan isu-isu penelitian dan permasalahan pada latar belakang, maka dapat dirumuskan pertanyaan penelitian dalam riset ini sebagai berikut. 
1. Apakah asimetri konflik tugas mempunyai pengaruh negatif terhadap kinerja kelompok?

2. Apakah manajemen konflik kolaborasi memoderasi (memperlemah) pengaruh negatif asimetri konflik tugas terhadap kinerja kelompok?

\section{Asimetri konflik tugas}

Jehn (1995) membagi konflik intragrup menjadi tiga jenis yaitu konflik hubungan, proses dan tugas. Yang menjadi fokus dalam penelitian ini adalah konflik tugas, yaitu konflik yang dapat memberikan manfaat bagi kelompok. Konflik tugas adalah ketidaksepahaman atau perbedaan sudut pandang diantara anggota grup terkait ide dan opini tentang tugas kelompok seperti strategi merekrut karyawan saat ini atau informasi yang sesuai untuk dimasukkan dalam laporan tahunan (Jehn, 1995). Konflik tugas terjadi ketika dua atau lebih individu di dalam organisasi tidak setuju pada konten dan solusi dari tugas-tugas yang dilakukan. Contoh konflik tugas adalah konflik tentang distribusi sumber daya, prosedur dan kebijakan, dan penilaian dan interpretasi fakta (Jehn, 1995; Jehn, 1997).

Asimetri konflik intragrup dibedakan dalam dua level analisis, yaitu asimetri konflik kelompok dan asimetri konflik individual (Jehn et al., 2010). Penelitian ini menitikberatkan pada level kelompok karena konflik intragrup adalah variabel yang berada pada level kelompok. Asimetri konflik kelompok merupakan konstruk level kelompok yang menunjukkan tingkat dimana anggota kelompok berbeda persepsi atas intensitas konflik yang terjadi dalam kelompoknya. Meskipun beberapa anggota mempunyai persepsi tinggi tentang intensitas konflik yang terjadi dalam kelompok, anggota lainnya mungkin memiliki persepsi yang rendah. Dispersi persepsi tentang intensitas konflik ini merupakan asimetri konflik level kelompok.

Penelitian ini mengkaji komposisi konflik tugas pada level kelompok, sesuai dengan karakteristik konflik intragrup yang merupakan konstruk level kelompok. Selain itu, kajian konflik pada level kelompok diharapkan dapat berimplikasi praktis bagi organisasi yang mengandalkan pencapaian kinerjanya melalui kinerja kelompok/tim.

\section{Manajemen Konflik Kolaborasi}

Konflik intragrup merupakan suatu hal yang tidak terhindarkan dalam hidup kelompok atau tim, mulai dari terbentuk sampai mencapai kinerjanya. Oleh karenanya individu dalam kelompok perlu mengelola konflik yang terjadi. Manajemen konflik merupakan proses untuk membatasi aspek negatif konflik dan untuk meningkatkan aspek positifnya (Rahim, 2002). Tujuannya adalah untuk meningkatkan pembelajaran 
dan luaran grup termasuk efektivitas atau kinerja organisasional. Beberapa riset telah menguji peran manajemen konflik (lihat De Dreu \& Van Vianen, 2001; Somech et al., 2009, dan Wang \& Nasr, 2010).

Studi Wang \& Nasr (2010) mengkaji tentang model taksonomi gaya penanganan konflik, yaitu Dual Concern Model. Model ini paling banyak diadopsi studi manajemen konflik interpersonal (Somech et al., 2009). Model dual concern membedakan 5 gaya spesifik penanganan konflik interpersonal yaitu kolaborasi, akomodasi, dominasi, penghindaran, dan kompromi (Somech et al., 2009).

Wang \& Nasr (2010) menjelaskan lima gaya manajemen konflik dalam Dual Model concern, diantaranya adalah manajemen konflik kolaborasi yang merupakan fokus dalam penelitian ini. Manajemen konflik kolaborasi mengindikasikan kepedulian yang tinggi untuk sepenuhnya memenuhi keinginan diri-sendiri dan pihak lain. Gaya manajemen konflik ini mengutamakan keterbukaan, pertukaran informasi, pencarian alternatif, dan mengeksplorasi perbedaan untuk menyelesaikan masalah yang dapat diterima oleh kedua belah pihak. Gambar 2.2 menunjukkan kelima gaya penanganan konflik interpersonal yang telah diuraikan tersebut.

Memperhatikan orang lain (kooperatif)

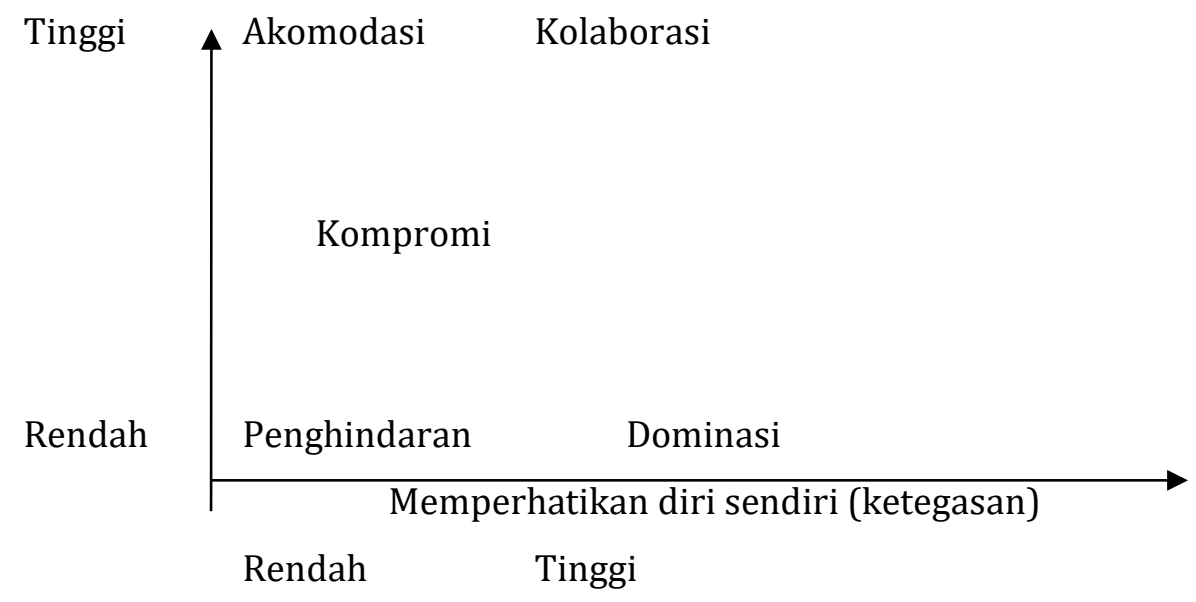

Gambar 2.2 Gaya Penanganan Konflik Interpersonal (diadaptasi dari Rahim dan Bonoma, 1979 dikutip dalam Wang \& Nasr, 2010) 


\section{Model Penelitian}

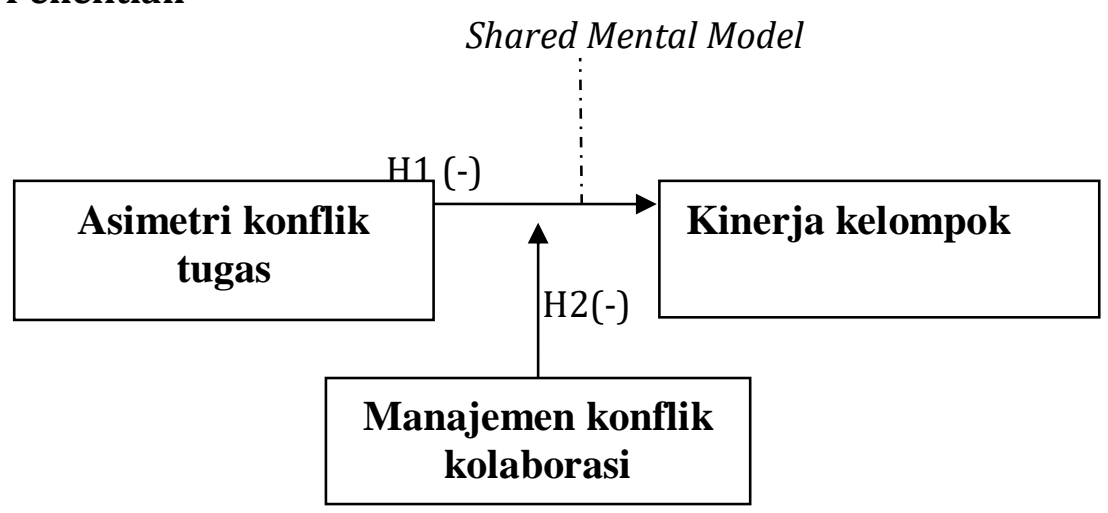

Gambar 2.1 Model Penelitian

\section{Metode Penelitian}

Penelitian ini menggunakan pendekatan kuantitatif dengan metode survei. Data dikumpulkan dengan kuesioner kepada responden. Responden adalah anggota kelompok kerja dari organisasi non profit. Semua data analisis dalam level kelompok. Variabel asimetri konflik tugas diukur dengan varian dari skor anggota kelompok. Adapun manajemen konflik kolaborasi dan kinerja kelompok diukur dengan mengagregasikan skor individu dalam kelompok.

Kuesioner penelitian ini menggunakan 6 indikator konflik tugas dari Jehn et al., (2008); 6 indikator manajemen konflik kolaborasi dari Wang dan Nasr (2010) dan 3 indikator kinerja kelompok dari Jehn et al. (2010). Dengan menggunakan skala likert, penelitian ini mengukur pendapat responden. Instrumen diukur dengan uji validitas menggunakan confirmatory factor analysis, dan uji reliabilitas dengan cronbah alpha. Analisis data dilakukan dengan analisis regresi hirarkis.

\section{Analisis Data dan Pembahasan}

Penelitian ini dilakukan pada organisasi non profit di kota Purwokerto. Organisasi tersebut meliputi lembaga level desa seperti LMD, PKK, Rukun kematian, dasa wisma, BKM, LP2A, RT; sekolah (TK dan SD), perpustakaan, organisasi intra kampus, pengelola jurusan/prodi Perguruan Tinggi Negeri, dan organisasi remaja masjid.

Penyebaran dan pengumpulan kuesioner dilakukan pada bulan Juli sampai dengan September 2018. Sebanyak 300 kuesioner terdistribusi pada 73 kelompok/tim kerja yang berasal dari 22 organisasi. Dari sebaran kuesioner tersebut sejumlah 288 kuesioner kembali (tingkat respon 96\%) berasal dari 68 kelompok/tim kerja (tingkat respon 93\%). Dalam 68 tim yang kembali, terdapat 58 tim (83\%) yang memenuhi syarat penyampelan, sehingga data dari 58 tim ini yang dianalisis. Tabel 1 berikut menyajikan pendistribusian dan penyebaran kuesioner. 
Tabel 1. Pendistribusian dan Pengembalian Kuesioner

\begin{tabular}{lcccc}
\hline $\begin{array}{c}\text { Kuesioner } \\
\text { Terdistribusi }\end{array}$ & $\begin{array}{c}\text { Kuesioner } \\
\text { Kembali }\end{array}$ & $\begin{array}{c}\text { Angka } \\
\text { Respon }\end{array}$ & $\begin{array}{c}\text { Kuesioner } \\
\text { Terpakai }\end{array}$ & $\begin{array}{c}\text { Persentase } \\
\text { Terpakai }\end{array}$ \\
\hline 300 kuesioner & 288 kuesioner & $96 \%$ & 232 kuesioner & $80 \%$ kuesioner \\
73 tim & 68 tim & $93 \%$ & 58 tim kerja & $90 \%$ tim kerja \\
22 organisasi & 22 organisasi & $100 \%$ & 18 organisasi & $82 \%$ \\
\hline
\end{tabular}

Ukuran tim yang berpartisipasi berkisar antara 3 sampai 9 orang dengan rata-rata 4 . Dari 288 kuesioner yang terkumpul, terdapat 232 kuesioner yang layak dianalisis secara statistik. Sisanya sebanyak 56 kuesioner tidak digunakan karena jumlah anggota tim kurang dari 3 orang, responden bekerja dalam tim kurang dari 3 bulan, atau responden tidak mengisi kuesioner dengan lengkap melebihi 5 persen dari seluruh item pertanyaan. Sesuai dengan rekomendasi Hair et al. (2014), bahwa data masih bisa digunakan jika jawaban 'tidak tahu' atau kosong tidak lebih dari 5 persen dari seluruh indikator.

Berdasarkan data profil responden, diketahui sebanyak 92 adalah laki-laki dan 127 perempuan, sisanya tidak menjawab. Umur responden $<20$ tahun sebanyak 60 orang, 2130 tahun sebanyak 60 orang, 31-40 tahun sebanyak 39 orang, 41-50 tahun sejumlah 34 orang, dan lebih dari 50 tahun sebanyak 32 orang. Berdasarkan pendidikan, 132 orang berpendidikan SMA, 21 orang Diploma 3, 49 orang berpendidikan S1, 7 berpendidikan S2, dan 5 orang berpedidikan S3, sisanya 18 orang tidak menjawab.

Hasil uji validitas dan reliabilitas menunjukkan bahwa semua indikator dalam penelitian ini memenuhi syarat valid (factor loading lebih besar dari 0,5) dan reliabel (koefisien Cronbah alpha konflik tugas=0,832; manajemen konflik kolaborasi=0,784, dan kinerja kelompok=0,767) sehingga layak digunakan untuk mengumpulkan data penelitian. Analisis data level kelompok dengan menggunakan rwg memastikan bahwa dari 68 tim yang terkumpul hanya 58 tim diantaranya yang memenuhi syarat agregasi. Oleh karenanya, analisis data hanya dilakukan pada data yang layak tersebut.

\section{Pengujian Hipotesis}

Hipotesis pertama menguji pengaruh komposisi komposisi konflik tugas perseptual terhadap kinerja kelompok. Hasil analisis regresi dapat dilihat pada Lampiran 4. Tabel 2 merangkum hasil pengujian hipotesis.

Tabel 2. Hasil Analisis Regresi Pengaruh Komposisi Koflik Tugas terhadap Kinerja Kelompok 


\begin{tabular}{llcccc}
\hline $\begin{array}{c}\text { Variabel } \\
\text { Independen }\end{array}$ & $\begin{array}{c}\text { Variabel } \\
\text { dependen }\end{array}$ & $\begin{array}{c}\text { Koefisien } \\
\text { Regresi }\end{array}$ & t value & F & $\begin{array}{c}\text { Keteranga } \\
\mathbf{n}\end{array}$ \\
\hline $\begin{array}{l}\text { Asimetri konflik } \\
\text { tugas }\end{array}$ & $\begin{array}{l}\text { Kinerja } \\
\text { Kelompok }\end{array}$ & $\beta=-0,233$ & $-2,066^{*}$ & $4,270^{*}$ & $\begin{array}{c}\text { Hipotesis } \\
\text { didukung }\end{array}$ \\
\hline
\end{tabular}

Hipotesis 2 menyatakan bahwa asimetri konflik tugas berpengaruh negatif terhadap kinerja kelompok. Untuk menguji hipotesis ini dilakukan analisis regresi hirarkis. Langkah pertama adalah meregresikan variabel kontrol yakni konflik tugas. Selanjutnya melakukan langkah kedua yaitu meregresikan variabel asimetri konflik tugas terhadap kinerja kelompok. Hasil pengujian regresi hirarkis dirangkum dalam Tabel 3.

Tabel 3. Hasil Analisis Regresi Hirarkis dengan Asimetri Konflik Tugas sebagai variabel Independen

\begin{tabular}{lcc}
\hline Variabel Independen & Langkah 1 & Langkah 2 \\
\hline Konflik Tugas & $-0,209$ & $-0,188$ \\
Komposisi Konflik Tugas & $-0,205$ & $-0,217$ \\
$\Delta \mathrm{R}^{2}$ & 0,108 & 0,147 \\
$\Delta \mathrm{F}$ & 4,458 & $3,112^{*}$ \\
Adj. $\mathrm{R}^{2}$ & 0,108 & 0,100 \\
Overall $\mathrm{R}^{2}$ & 0,139 & 0,089 \\
Overall $\mathrm{F}$ & 4,458 & $3,112^{*}$ \\
\hline
\end{tabular}

Catatan: ${ }^{*} \mathrm{p}<0,05 ;{ }^{* *} \mathrm{p}<0,01$

Hasil pengujian menunjukkan bahwa dengan memasukkan asimetri konflik tugas dalam persamaan regresi, perubahan $\mathrm{R}^{2}$ pada langkah pertama dan kedua adalah signifikan secara statistik $\left(\Delta R^{2}=0,100, \Delta F=3,112, p<0,05\right)$.

Hipotesis 2 menyatakan bahwa manajemen konflik kolaborasi memoderasi (memperlemah) pengaruh negatif komposisi konflik terhadap kinerja kelompok. Untuk menguji hipotesis ini dilakukan 3 langkah analisis regresi hirarkis (Cohen, Cohen, West, \& Aiken, 2003). Langkah pertama, meregresikan variabel kontrol yaitu konflik tugas. Langkah kedua, meregresikan variabel komposisi konflik tugas dengan variabel kinerja kelompok. Sebelum melakukan langkah ketiga, masing-masing variabel asimetri konflik tugas dan manajemen konflik kolaborasi dilakukan proses mean centering (Aiken \& West, 1991). Selanjutnya, peneliti memasukkan hasil interaksi antara kedua variabel tersebut. Hasil pengujian hipotesis 3 dapat dilihat pada Tabel 4.

Tabel 4. Hasil Regresi Hirarkis dengan Variabel Asimetri Konflik Tugas sebagai Variabel Independen (Moderator: Manajemen Konflik Kolaborasi)

\begin{tabular}{lccc}
\hline \multicolumn{1}{c}{ Variabel Independen } & Langkah $\mathbf{1}$ & Langkah 2 & Langkah 3 \\
\hline Konflik Tugas & $-0,209$ & $-0,188$ & $-0,177$ \\
Komposisi Konflik Tugas & 0,108 & 0,147 & 0,206 \\
Manajemen Konflik Kolaborasi (MKK) & 4,458 & $3,112^{*}$ & 0,017 \\
AKT x MKK & 0,108 & 0,100 & 0,019 \\
$\Delta \mathrm{R}^{2}$ & 0,139 & 0,089 & 0,132 \\
\hline
\end{tabular}




\begin{tabular}{lccc}
\hline \multicolumn{1}{c}{ Variabel Independen } & Langkah 1 & Langkah 2 & Langkah 3 \\
\hline$\Delta \mathrm{F}$ & 4,458 & $3,112^{*}$ & 1,976 \\
Adj. $\mathrm{R}^{2}$ & $-0,209$ & $-0,188$ & 0,065 \\
Overall $\mathrm{R}^{2}$ & $-0,205$ & $-0,217$ & 0,132 \\
Overall $\mathrm{F}$ & 0,108 & 0,147 & 1.112 \\
\hline
\end{tabular}

Catatan: ${ }^{*} \mathrm{p}<0,05 ;{ }^{* *} \mathrm{p}<0,01$

Pada langkah pertama, diketahui bahwa variabel kontrol tidak berpengaruh terhadap kinerja kelompok. Setelah dilakukan langkah kedua, terlihat bahwa manajemen konflik kolaborasi mempunyai pengaruh positif signifikan terhadap kinerja kelompok. Langkah kedua ini juga menunjukkan perubahan F signifikan. Selanjutnya langkah ketiga menunjukkan bahwa manajemen konflik kolaborasi tidak berpengaruh signifikan terhadap kinerja kelompok. Selain itu juga terlihat dalam Tabel 4 bahwa interaction term tidak memberikan perubahan signifikan pada $\mathrm{R}^{2}$. Pengaruh interaksi antara manajemen konflik kolaborasi dan asimetri konflik tugas adalah tidak signifikan. Hal ini berarti manajemen konflik kolaborasi tidak mengurangi pengaruh positif asimteri konflik tugas terhadap kinerja kelompok. Oleh karenanya, Hipotesis 2 yang menyatakan bahwa manajemen konflik kolaborasi memoderasi pengaruh komposisi konflik tugas terhadap kinerja kelompok, tidak didukung.

\section{Pembahasan}

Penelitian ini berfokus pada konflik tugas dalam pandangan asimetri. Konsep asimetri konflik tugas ini mengacu pada perbedaan persepsi anggota kelompok akan intensitas konflik tugas yang terjadi pada kelompok. Jehn et al. (2010a) menemukan bahwa asimetri konflik tugas dalam kelompok berpengaruh pada luaran melebihi dari pengaruh rata-ratanya. Tabel 5 merangkum hasil penelitian ini.

Tabel 5. Rangkuman Hasil Pengujian Hipotesis

\begin{tabular}{lcc}
\hline \multicolumn{1}{c}{ Hipotesis } & \multicolumn{2}{c}{ Hasil Pengujian } \\
\hline $\begin{array}{l}\text { Hipotesis 1. } \\
\text { berhubungan } \begin{array}{c}\text { nsimetri konflik tugas } \\
\text { kreativitas kelompok. }\end{array}\end{array}$ & $\begin{array}{c}\text { Didukung } \\
\text { signifikan }\end{array}$ & $\begin{array}{l}\text { Berpengaruh negatif } \\
\text { Hipotesis 2. Manajemen konflik }\end{array}$ \\
$\begin{array}{l}\text { kolaborasi memoderasi } \\
\text { (memperlemah) pengaruh komposisi }\end{array}$ & Didukung & $\begin{array}{c}\text { Efek pemoderasian } \\
\text { tidak signifikan. }\end{array}$ \\
$\begin{array}{l}\text { konflik tugas perseptual terhadap } \\
\text { kinerja kelompok. }\end{array}$ & & \\
\hline
\end{tabular}

Hasil analisis menunjukkan bahwa perbedaan persespsi anggota terkait dengan konflik tugas berpengaruh negatif terhadap kinerja kelompok. Semakin beragam persepsi anggota, semakin memperburuk kinerja kelompok. Penelitian ini mendukung 
riset terdahulu (Jehn, 2010; De Dreu \& Weingart, 2003) yang menunjukkan bahwa perbedaan persespi tentang intensitas konflik dalam kelompok merupakan hal yang berdampak buruk terhadap kinerja kelompok. Demikian juga hasil penelitian juga mendukung teori shared mental model yang mensyaratkan anggota kelompok mempunyai persepsi bersama untuk mencapai kinerja yang baik.

Penelitian ini tidak mendukung peran manajemen konflik kolaborasi dalam memperlemah pengaruh negatif asimetri konflik tugas terhadap kinerja kelompok. Hal ini kemungkinan disebabkan oleh karakteristik responden yang berasal dari organisasi non profit. Organisasi jenis ini tidak banyak mengalami konflik terkait tugas kelompok. Hal ini ditunjukkan bahwa rata-rata intensitas konflik yang dipersepsikan oleh respon adalah 1,6 (skala 5 poin). Skor 1,6 menunjukkan bahwa responden memersepsikan konflik tugas dalam kelompok berada dalam kategori rendah atau sedikit.

Hasil penelitian ini menunjukkan bahwa skor rata-rata manajemen konflik kolaborasi menunjukkan nilai 4,928 (skor 5 poin). Hal ini merupakan nilai yang tinggi untuk item-item yang diukur dalam manajemen konflik tugas. Artinya, umumnya anggota kelompok menggunakan manajemen konflik ini untuk menyelesaikan konflik tugas yang terjadi. Hasil analisis menunjukkan bahwa manajemen konflik kolaborasi tidak signifikan mengurangi pengaruh konflik tugas dengan intensitas rendah terhadap kinerja kelompok.

\section{Simpulan}

Penelitian ini berfokus pada konflik tugas dalam pandangan asimetri (lihat De Witt et al., 2012), sisi yang sering diabaikan oleh peneliti konflik intragrup terdahulu (seperti Amason, 1996; Jehn et al., 1999, Shaw et al., 2011; De Church et al., 2013; Chang, 2017). Dengan menggunakan pendekatan share mental model (SMM), penelitian ini juga menguji pengaruh negatif asimetri konflik tugas terhadap kinerja kelompok. Selanjutnya, studi ini juga menguji peran pemoderasian manajemen konflik kolaborasi (Wang \& Nasr, 2010) pada pengaruh asimetri konflik terhadap kinerja kelompok.

Penelitian ini melibatkan berbagai jenis organisasi non profit. Dengan menggunakan kuesioner dalam pengumpulan datanya, diperoleh 58 tim atau 232 responden yang memenuhi syarat penyampelan dan layak dianalisis secara stastistik. Analisis faktor konfirmatori digunakan untuk uji validitas dan Cronbach Alpha untuk menguji reliabilitas variabel. Hasilnya diperoleh item-item valid dan variabel yang reliabel sesuai dengan yang disyaratkan (Hair et al., 2014).

Untuk menguji hipotesis digunakan alat analisis regresi liner hirarkis. Analisis terhadap data menghasilkan simpulan sebagai berikut: 
Komposisi konflik tugas perseptual berpengaruh negatif terhadap jinerja kelompok. Semakin beragam persepsi anggota terhadap tugas, maka semakin buruk kinerja sebuah kelompok. Perbedaaan persepsi anggota dalam kelompok terkait dengan tugas akan menghasilkan keadaan yang membuat anggota merasa tertekan. Sumber daya kelompok akan terkuras untuk menyamakan persepsi tentang tugas yang dibebankan kepada kelompok. Akibatnya, energi yang dimiliki anggota tidak bisa langsung digunakan untuk mencapai kinerja. Oleh karenanya semakin beragam persespi anggota terkait dengan tugas, maka semakin menurun kinerja kelompok. Temuan ini mengonfirmasi hipotesis penelitian yang memprediksi pengaruh negatif komposisi konflik tugas terhadap kinerja kelompok, sekaligus mendukung pendekatan share mental model (Mathieu et al., 2000), yang digunakan peneliti untuk mendasari pengaruh negatif tersebut.

Temuan kedua adalah bahwa manajemen konflik kolaborasi tidak mempunyai peran pemoderasian pada pengaruh asimetri konflik tugas terhadap kinerja kelompok. Temuan ini mendukung teori TKKS (Bandura, 1999), yang menyatakan bahwa perilaku individu merupakan interaksi antara perilaku (kinerja dan asimetri konflik tugas), kepribadian dan lingkungan (manajemen konflik kolaborasi).

\section{Implikasi}

Secara umum penelitian ini memberikan dukungan terhadap konsep asimetri konflik dalam kelompok dan teori yang mendasari kerangka pikir model asimetri konflik dalam kelompok. Berikut adalah sejumlah kontribusi penelitian ini. Kontribusi pertama, penelitian ini memperkuat pandangan asimetri terhadap konflik (lihat Jehn \& Chatman, 2000, Jehn et al., 2006; Jehn et al., 2008, Jehn et al., 2010a, Jehn et al. 2010, Jehn et al., 2011; Jehn et al., 2015, Karaca, 2016; Kim, 2017). Hasil penelitian ini menunjukkan bahwa bukan saja rata-rata konflik (pandangan simetri terhadap intensitas konflik) yang berpengaruh pada luaran tetapi perbedaan persepsi tentang intensitas konflik (komposisi konflik) juga akan berpengaruh pada luaran konflik tugas.

Hasil penelitian ini mendukung penelitian sebelumnya (Jehn et al., 2010) yang menemukan pengaruh negatif asimetri konflik tugas terhadap kinerja kelompok. Temuan ini mendukung pendekatan share mental model yang menganggap bahwa untuk mendapatkan kinerja tim yang baik diperlukan kesamaan persepsi, informasi dan pengetahuan diantara anggotanya.

Kontribusi keempat penelitian ini adalah bahwa temuan studi ini menyatakan bahwa manajemen konflik kolaborasi (Wang \& Nasr, 2010) sebagai gaya penanganan 
konflik yang paling disukai oleh pihak yang berkonflik, tidak selamanya menguntungkan. Temuan studi ini justru menunjukkan bahwa manajemen konflik kolaborasi tiadak berdampak pada kinerja kelompok.

Hasil studi ini juga menunjukkan bahwa asimetri konflik tugas akan menurunkan kinerja kelompok. Untuk itu, guna menghasilkan kelompok dengan berkinerja tinggi, maka diperlukan persamaan persepsi diantara anggotanya. Mengacu pada temuan dari penelitian ini bahwa manajemen konflik kolaborasi yang tidak pengaruh positif asimetri konflik tugas terhadap kinerja kelompok, maka sebaiknya manajemen tidak menggunakan strategi penanganan konflik kolaborasi jika menginginkan kelompok yang berkinerja tinggi.

\section{Keterbatasan dan Saran bagi Penelitian Mendatang}

Penelitian ini memiliki sejumlah keterbatasan yang dapat diperbaiki untuk penelitian mendatang. Penelitian ini menggunakan desain cross sectional. Pengumpulan data membutuhkan waktu 3 bulan. Sementara itu konflik intragrup adalah fenomena yang bersifat dinamis yang tidak bisa hanya ditangkap pada satu waktu. Oleh karenanya, perlu kehati-hatian dalam memaknai temuan dalam penelitian ini. Temuan ini menunjukkan bahwa asimetri konflik tugas mempunyai hubungan negatif linier terhadap asimetri konflik tugas.

\section{DAFTAR PUSTAKA}

Amason, A. C. (1996). Distinguishing the effect of functional and dysfunctional conflict on strategic decision making: Resolving a paradox for top management team. Academy of Management Journal, 39(1): 123-148.

Bradley, B. H., Postlethwaite, B. E, Klotz, A. C., Hamdani, M. R., \& Brown, K. G. (2012). Reaping the benefits of task conflict in teams: The critical role of team psychological safety climate. Journal of Applied Psychology, 97(1): 151-158.

Chang, M-L. 2017. On the relationship between intragroup conflict and social capital in teams: A longitudinal investigation in Taiwan. Journal of organizational behavior, 38(1): 3-27.

Cohen, J., Cohen, P., West, S. G., \& Aiken, L.S. (2003). Applied multiple regression/correlation analysis for behavioral sciences, NL: Lawerence Erlbaum.

De Church, L. A., Mesmer-Magnus, J. L., Doty, D. (2013). Moving beyond relationship and task conflict: Toward a process-state perspective. Journal of Applied Psychology,98(4): 559-578.

De Dreu, C. K. W. \& Weingart, L. R. (2003). Task vs relationship conflict, team performance and team member satisfaction: a meta-analysis. Journal of Applied Psychology, 88(4): 741-749. 
De Dreu, C.K.W \& Van Vianen, A. E. M. (2001). Managing relationship conflict and the effectiveness of organizational teams. Journal of Organizational Behavior, 11: 309328.

Hair Jr, J. F., Hult, G.T. M , Ringle, C.M., \& Sarstedt, M. (2014). A Primer on Partial Least Squares Structural Equation Modeling (PLS-SEM). Sage Publications Asia-Pacific Pte. Ltd.

Jehn, K. A. (1995). A multimethod examination of the benefits and detriments of intragroup conflict. Administrative Science Quarterly, 40(2): 256

Jehn, K. A. (1997). A Qualitative analysis of conflict types and dimensions in organizational groups. Administrative Science Quarterly, 42(3): 503-557.

Jehn, K. A., Northcraft, G. B., \& Neale, M. A. (1999). Why differences make a difference: A field study of diversity, conflict and performance in workgroups. Administrative Science Quarterly, 44(1):741-763.

Jehn, K. A., \& Chatman, J. A. (2000). The influence of proportional and perceptual conflict composition. The International Journal of Conflict Management.11(1): 56-73.

Jehn, K. A., Rupert, J., \& Nauta, A. (2006). The effect of conflict asymmetry on mediation outcome: satisfaction, work motivation and absenteeism. International Journal of Conflict Management, 17(2): 96-109.

Jehn, K. A., Greer, L., Levine, S., \& Szulanski, G. (2008). The effect of conflict types, dimensions and emergent states on group outcomes. Group Decision Negotiation. 17: 465-495.

Jehn, K. A., Rispens, S., \& Thatcher, S. M. B. (2010a). The effects of conflict asymmetry on work group and individual outcomes. Academy of Management Journal, 53(3): 596.

Jehn, K. A., Rupert, J., \& Nauta, A., (2010b). Crooked Conflict: The effect of asymmetry conflict in mediation. Negotiation and conflict Management Research, 3(4):338357.

Jehn, K. A., Peterson, R., \& Burks, J. S. (2011). Seeing the world through different eyes: The effect of conflict belief asymmetry on work group performance. 24rd Annual International Association of Conflict Management Conference Instanbul, Turkey July 3-6.

Jehn, K. A., De Wit, F. R. C., Barreto, M., \& Rink, F. (2015). Task conflict asymmetries: effects on expectations and performance. International Journal of Conflict Management, 26(2): 172-191.

Karaca, A., (2016). Conflict about conflict: antecedents, consequences, and moderators of conflict asymmetry in teams. Wayne State University Dissertations. http://digitalcommons.wayne.edu/oa_dissertations/1643.

Mathieu, J. E., Heffner, T. S., Goodwin, G. F., Salas, E. \& Cannon-Bowers, A. (2000). The influence of shared mental model on team process and performance. Journal of Applied Psychology, 85(2): 273-283. 
Rahim, M. A. (2002). Toward theory of managing organizational conflict. The International Journal of Conflict Management, 13(2): 206-235.

Somech, A., Desivilya, H. S., \& Lidogoster, H. (2009). Team conflict management and team effectiveness: The effect of task interdependence an team identification. Journal of Organizational Behavior, 30(3): 359-378.

Shaw, J. D., Zhu, J., Duffy, M. K., Scott, K. L., Shih, H. A., \& Susanto, E. (2011). A contingency model of conflict and team effectiveness. Journal of Applied Psychology. 96(2): 391-400.

Tjosvold, D. (2008). The conflict-positive organization: it depends upon us. Journal of Organizational Behavior, 29(1): 19-28.

Wall, J. A., \& Callister, R. B. (1995). Conflict and its management. Journal of Management, 21(3): 515-558.

Wang, H. \& Nasr, Y. A. (2010). Task conflict handling styles between colleagues with bad personal relationship: The effect of relationship conflict on task conflict. Umea School of Business. Master Thesis. 